\title{
A Comparative Study of Role Stress in Government and Private Hospital Doctors
}

\section{Chirag Rathod* \\ ABSTRACT:}

The main objective of the present study is to examine the role stress among government and private doctors. A sample of 60 male and female doctors was drawn randomly drawn from the population. The organizational role stress (ORS) developed by Pareek was used for data collection. Data was collected by face to face interview method from the target population from different hospitals of Anand district. Mean, standard deviation and t-test were calculated for the analysis of data. Results indicate that there is no significant difference among government and private doctors in role of stress.

Keywords: Stress, Government and Private Hospitals Doctors

\section{INTRODUCTION}

Stress is a feeling of tension or pressure that people experience when demands placed on them exceed the resources they have to meet these demands (Moore, 1995). There is a considerable debate among stress researchers about how to adequately define stress. According to Selye (1956), “Any external event or internal drive which threatens to upset the organism's equilibrium is stress." He has defined stress as the non-specific response of the body to any demand made upon it. Lazarus (1980) sees Stress as a result of a transaction between person and environment. Zimbardo (1988) defined stress as "the pattern of specific and non-specific responses an organism makes to stimulus events that disturbs its equilibrium and exceed its ability to cope. From the foregoing definitions it may be pointed out that the researchers explained the notion of stress from various perspectives: i) as an external force which is perceived as threatening; ii) as response to a situation demanding an individual to adapt to change, physically or psychologically; iii) as an interactional outcome of the external demand and internal resources; iv) as personal response to certain variations in the environment and v) a more comprehensive combination of all. Pestonjee (1992) has identified 3 important sectors of life in which stress originates (i) Organizational\& Job sector (ii) Social sector and (iii) Intrapsychic sector. The focus of the present study is to understand stress in organizational/ job sector of life. Organizational/ Job stress has been defined in terms of a misfit between person "s skills \& abilities and the -

*MA, Clinical Psychology, Dept. of Psychology, Sardar Patel University, Vallabh Vidhyanagar, Guj. Ind

(C) 2014 C Rathod; licensee IJIP. This is an Open Access Research distributed under the terms of the Creative Commons Attribution License (http://creativecommons.org/licenses/by/2.0), which permits unrestricted use, distribution, and reproduction in any Medium, provided the original work is properly cited. 
- demands of his/her job. The concept of Organizational/job stress falls under the umbrella of a broader concept i.e. Role Stress. Therefore, it becomes imperative to understand the concept of Organizational role, in order to understand the concept of stress in Organizational \& job sector of life. According to Pareek (1993), Role denotes the set of functions one performs in response to the expectations of the significant others, and one's own expectations from that position or office. The organization and individual come together through role. Pareek (1980) pioneered work on role by identifying as many as 10 different types of organizational role stresses. Briefly these are: Inter Role Distance (IRD): Conflict between organizational and non-organizational roles. Role Stagnation (RS): "Feeling of being stuck in the same role." It results in the perception that there is no opportunity for learning \& growth in the role. Role Expectation Conflict (REC): Conflicting demands made on the role by role senders. Role Erosion (RE): Feeling of "Responsibility without power." It is a feeling that some important functions a role occupant would like to perform has been given to some other roles. Role Overload (RO): A feeling that too much is expected from the role than what the occupant can cope with. Role Isolation (RI): Lack of linkages of one's role with other roles in the organization. Personal Inadequacy (PI): Lack of knowledge, skills or adequate preparation to be effective in a particular job. Self- Role Distance Conflicts of one "values and self-concepts with the requirements of the organizational role. Role Ambiguity Lack of clarity about expectations of others from the role, or lack of feedback on how performance is regarded by others. Resource Inadequacy Non-availability of resources needed for effective role performance.

\section{OBJECTIVES}

1. To study role stress in doctors working in Government and Private Hospitals.

2. To study role stress in male and female doctors working in Government Hospitals.

3. To study role stress in male and female doctors working in Private Hospitals.

\section{HYPOTHESIS}

1. There is no significant difference in Government and Private Hospitals doctors, about role stress.

2. There is no significant difference in male and female doctors of Government Hospitals.

3. There is no significant difference in male and female doctors of Private Hospitals.

\section{VARIABLES}

\section{- Independent Variables:}

Government and Private Hospitals doctors, Gender

\section{- Dependent Variable:}

Role Stress 


\section{TOOLS}

The organizational role stress (ORS) scale, which was developed and standardized by Pareek in the year 1981 to measure the role stress, has been used in this study. The ORS scale is a 5 point scale (0-4) consisting of 50 statements which measures 10 role stressors $(5$ statements for each role stressor).

\section{POPULATION}

The population selected for this particular study is doctors of government \& private hospitals of different service sectors in Anand District (Gujarat State).

\section{SAMPLING}

The sampling population of this research includes 60 doctors of government $\&$ private hospitals of different service sectors. This research followed the random sampling method representative population.

\section{ANALYSIS FORMULA}

Here in this study the $\mathrm{t}^{\mathrm{ec}}$-Test was conducted as a statistical technique to prove the aim.

\section{RESULTS AND DISSECTION}

1. Table, Role stress in doctors working in Government and Private Hospitals.

\begin{tabular}{|l|l|l|l|l|l|l|}
\hline \multicolumn{1}{|c|}{ Group } & \multicolumn{1}{c|}{ N } & \multicolumn{1}{c|}{ Mean } & \multicolumn{1}{c|}{ SD } & \multicolumn{1}{c|}{ SEM } & \multicolumn{1}{c|}{ t } & \multicolumn{1}{c|}{ Level } \\
\hline Government & 30 & 33.53 & 5.56 & 1.01 & 1.6497 & NS \\
\cline { 1 - 5 } Private & 30 & 36.13 & 6.61 & 1.21 & & 0.01 \\
\hline
\end{tabular}

The above table no. 1 shows the mean difference between two groups (government and private hospitals) in terms of role stress. The mean for the government doctors is 33.53 and SD 5.56, as well as the mean of private doctors is 36.13 and SD 6.61. The obtained " $t^{\text {ee }}$ is 1.6497 , which is no significant at 0.01 levels. Hence it is concluded that there is no significant difference between government and private doctors in terms of their role stress.

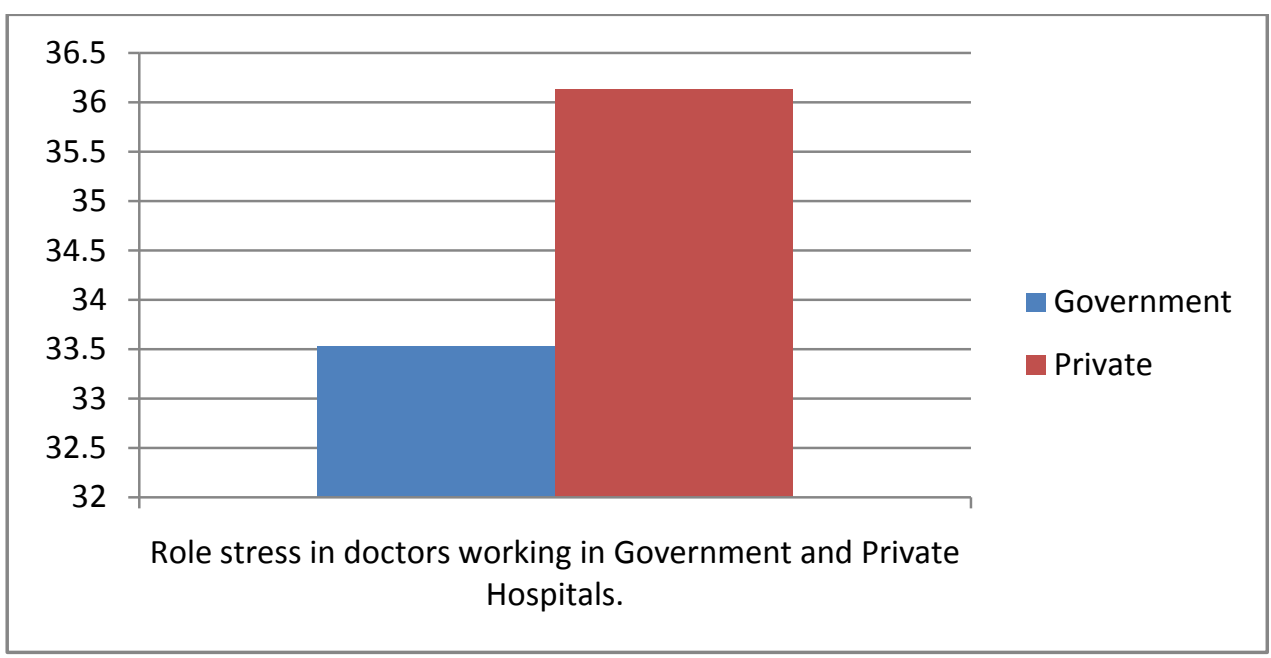


2. Table, Role stress in male and female doctors working in Government Hospitals.

\begin{tabular}{|l|l|l|l|l|l|l|}
\hline \multicolumn{1}{|c|}{ Group } & \multicolumn{1}{c|}{$\mathbf{N}$} & \multicolumn{1}{c|}{ Mean } & \multicolumn{1}{c|}{ SD } & \multicolumn{1}{c|}{ SEM } & \multicolumn{1}{c|}{ t } & \multicolumn{1}{c|}{ Level } \\
\hline Male doctors & 15 & 33.60 & 6.13 & 1.58 & 0.0646 & NS \\
\hline $\begin{array}{l}\text { Female } \\
\text { doctors }\end{array}$ & 15 & 33.47 & 5.14 & 1.33 & & 0.01 \\
\hline
\end{tabular}

The above table no. 2 shows the mean difference between two groups (male and female) in terms of role stress. The mean for the government male doctors is 33.60 and SD 5.56, as well as the mean of female doctors is 33.47 and SD 5.14. The obtained "ete is 0.0646 , which is no significant at 0.01 levels. Hence it is concluded that there is no significant difference between government male and female doctors in terms of their role stress.

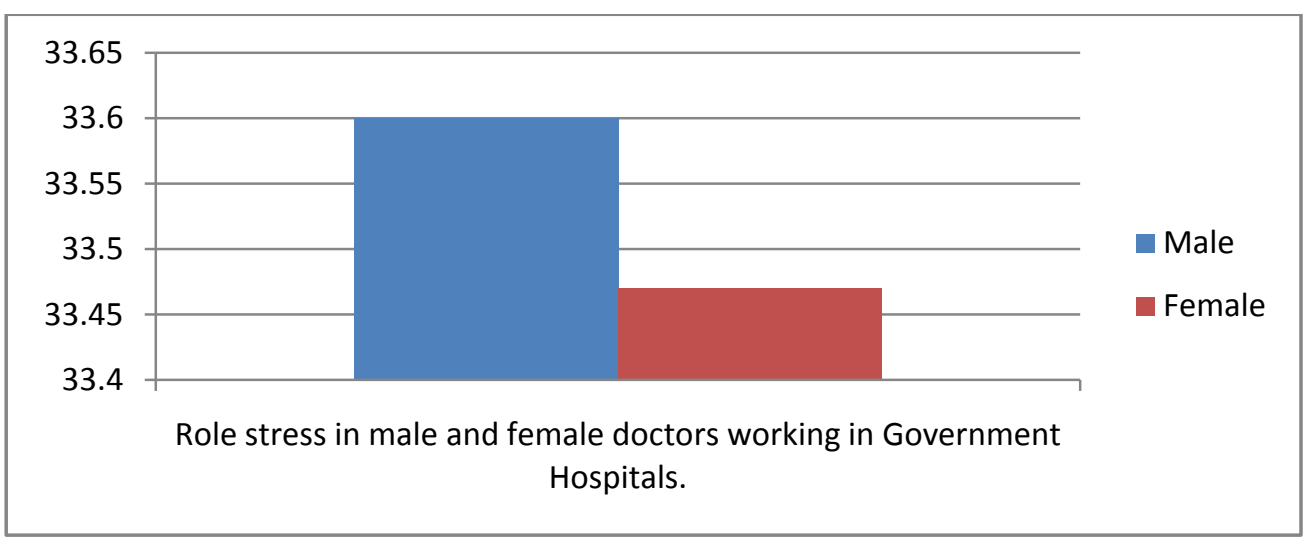

3. Table, Role stress in male and female doctors working in Private Hospitals.

\begin{tabular}{|c|c|c|c|c|c|c|}
\hline Group & $\mathbf{N}$ & Mean & SD & SEM & $\mathbf{t}$ & Level \\
\hline Male doctors & 15 & 37.80 & 3.51 & 0.91 & \multirow[t]{2}{*}{1.4049} & \multirow{2}{*}{$\begin{array}{l}\text { NS } \\
0.01\end{array}$} \\
\hline $\begin{array}{l}\text { Female } \\
\text { doctors }\end{array}$ & 15 & 34.47 & 8.49 & 2.19 & & \\
\hline
\end{tabular}

The above table no. 3 shows the mean difference between two groups (male and female) in terms of role stress. The mean for the private male doctors is 37.80 and SD 3.51, as well as the mean of female doctors is 34.47 and SD 8.49. The obtained "ete is 1.4049 , which is no significant at 0.01 levels. Hence it is concluded that there is no significant difference between private male and female doctors in terms of their role stress.

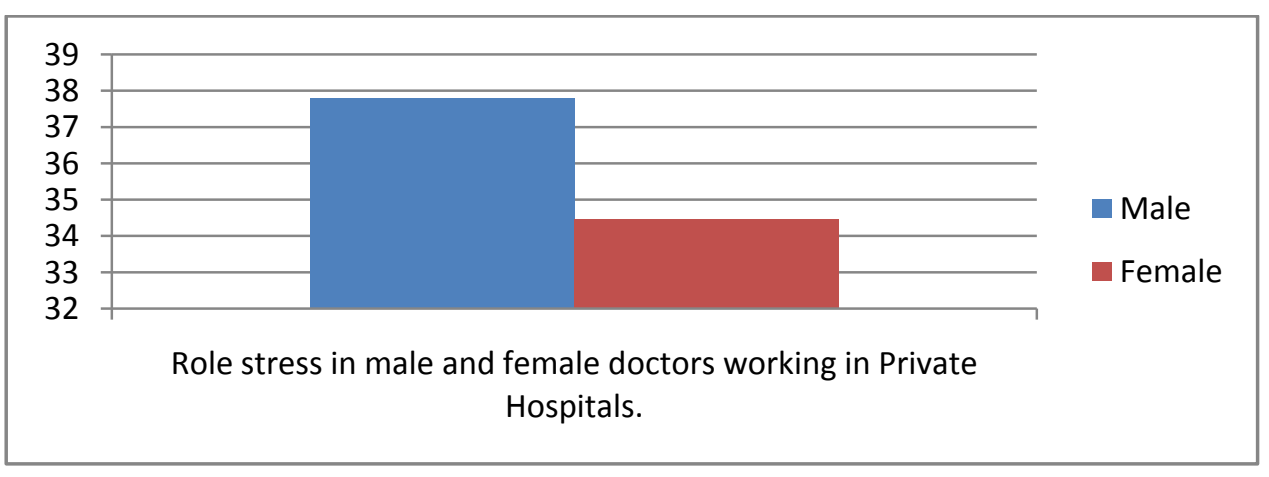




\section{CONCLUSION}

1. No significant difference in Government and Private Hospitals doctors, about role stress, so we accept null hypothesis.

2. No significant difference in male and female doctors of Government Hospitals.

3. No significant difference in male and female doctors of Private Hospitals.

\section{REFERENCE}

1. Allibone, A. Oakes, D. \& Shannon, H.S., 1981. The health and healthcare of doctors. Journal of the Royal College of General Practitioners, 31, pp. 728-731.

2. British Medical Association. Stress and the medical profession, London: BMA 2000.

3. Burke, RJ.\&Richardson, AM., 1991. Sources of satisfaction and stress among Canadian physicians.Psychol Rep, 67, pp. 1335-1344.

4. Chambers, R., 1992. The health and lifestyle of general practitioners and teachers. Occupational Medicine, 42, pp. 69-78.

5. Cooper, C.L., Rout, U. \&Faragher, B., 1989. Mental health, Job Satisfaction, and Job Stress among general practitioners. British Medical Journal, 298, pp. 366-370.

6. Gestal,JJ., 1987. Occupational hazards in hospitals: accidents, radiation, exposure to noxious chemicals, drug addiction and psychic problems and assault. BMJ, 44, pp. 510-520.

7. Gianakos, Irene. 2001. Gender Roles and Coping with work stress. Sex Roles. A Journal of Research (6),pp. 1-13.

8. Hirak, Dasgupta\& Suresh, Kumar.,2009.Role Stress among Doctors Working in a Government Hospital n Shimla (India). European Journal of Social Sciences 9 (3),pp. 356370.

9. 1.-Aameri.\&Al-Fawzan., 1998. Nurses ${ }^{\text {ee }}$ strategies for coping with job stress. Saudi Medical Journal, 19 (4), pp. 366-371. 